FE640

\title{
A Survey of Education Program Needs for the Florida Association of Counties County Commissioner Training Program, 1998-2000
}

\author{
Rodney L. Clouser
}

\section{INTRODUCTION}

Florida Cooperative Extension has partnered with the Florida Association of Counties (FAC) and the Florida Counties Foundation (FCF) since 1998 in surveying Florida County Commissioners and County Administrators approximately every two years. The survey collects information regarding attendance at FAC-FCF sponsored events, willingness to pay for educational programs, worth of events and programs attended by commissioners and administrators, desired locations for educational activities and, most importantly, the type and amount of training needed by commissioners on various topics that would assist them as an elected policy maker.

The results of the 1998-2000 survey are presented as an executive summary that follows. In addition, the survey questionnaire and PowerPoint presentation of results are being made available via a link for those who would like to view or print the entire document.

\footnotetext{
The Institute of Food and Agricultural Sciences (IFAS) is an Equal Opportunity Institution authorized to provide research, educational information, and other services only to individuals and institutions that function with non-discrimination with respect to race, creed, color, religion, age, disability, sex, sexual orientation, marital status, national origin, political opinions, or affiliations. U.S. Department of Agriculture, Cooperative Extension Service, University of Florida, IFAS, Florida A\&M University Cooperative Extension Program, and Boards of County Commissioners. Larry Arrington, Dean.
}

This is EDIS document FE640, a publication of the Food and Resource Economics Department, Florida Cooperative Extension Service, Institute of Food and Agricultural Sciences, University of Florida, Gainesville, FL. Published June 2006. Please visit the EDIS website at http://edis.ifas.ufl.edu. 


\title{
A Survey of Educational Program Needs for the Florida Association of Counties County Commissioner Training Program, 1998-2000
}

\author{
Rodney L. Clouser ${ }^{1}$
}

\section{EXECUTIVE SUMMARY}

\section{8-2000 County Commissioner and County Administrator Educational Survey}

A survey of educational program needs for Florida County Commissioners and County Administrators was conducted by the Florida Counties Foundation (FCF) and Florida Cooperative Extension Service (FCES), IFAS, University of Florida in the spring of 1998. The intent of the survey was to solicit educational training needs to assist FCF in developing educational programs for 1998-2000. A total of 374 County Commissioners and 68 County Administrators were surveyed. Thirty-two percent (141 surveys) of those survey supplied responses. A summary of the survey follows:

1. About six in ten commissioners attend the Florida Association of Counties (FAC) annual conference on a regular basis and over eight in ten attend the conference regularly or periodically.

2. The number of officials who attend the annual legislative conference is similar to the number who attends the annual conference but slightly fewer attend the legislative conference on a regular basis (5 in 10).

3. About two-thirds of all respondents had attended an educational program of FAC/FCF.

4. Almost 38 percent of respondents had attended two or more educational programs and 40 percent had attended no educational programs during the past year.

5. In excess of 90 percent of respondents found FCF educational programs at least sometimes beneficial. Over 57 percent indicated the FCF educational programs were always helpful.

6. An overwhelming number of respondents (81 percent) prefer weekday training programs.

7. About two out of every three surveyed preferred educational programs that lasted six hours.

8. Over 57 percent have a preference for educational workshops that cover multiple topics.

9. Almost 82 percent would be willing to pay fees of $\$ 100$ for educational programs.

\footnotetext{
${ }^{1}$ Professor and Extension Public Policy Specialist, Food and Resource Economics Department, University of Florida, Gainesville, FL.
} 
10. The most important factor in determining attendance at workshops was the topic covered. The least important factor influencing workshop attendance was date/time followed by location.

11. About 75 percent of those surveyed agreed or strongly agreed that the voluntary commissioner certification program should be continued.

12. Twenty-four different topics were identified by about 15 percent of respondents as areas where educational training programs for commissioners would be beneficial. The top educational topics of interest to commissioners were: economic development, planning/zoning and county government services.

13. When asked to list the three most important topics for commissioner training, those identified were: economic development, planning/zoning and tied for third was transportation and environment/water/landfill issues.

14. Twenty-two different topics were identified by about 15 percent of respondents as areas where county government staff training would be helpful. The top educational topics of interest for county staff were: effective communication, economic development and planning/zoning issues.

15. When asked to list the three most important topics for county staff training those identified were: effective communication, economic development and leadership issues.

16. About 80 percent of those responding had served less than eight years in their position with almost 50 percent having served three to eight years.

\section{Summary}

Participation and returns of surveys by county commissioners and county administrators increased with a more formalized survey. Prior to University of Florida Cooperative Extension becoming involved with the survey the typical response rate was about 15 percent. In 1998, the survey response rate increased to 32 percent.

From an educational standpoint, the most important needs of those serving as county commissioners or administrators are:

- The top educational topics of interest to commissioners were: economic development, planning/zoning and county government services.

- Commissioners and Administrators felt that the most important training needs for staff were effective communication, economic development and planning/zoning issues. 


\section{FLORIDA COUNTIES FOUNDATION SURVEY}

1. I attend the Florida Association of Counties (FAC) Annual Conference.

_ Regularly __ Sometimes_ _ Rarely _ _ Never

2. I attend the FAC Legislative Conference and/or Legislative Day.

_ Regularly_ __ Sometimes__ Rarely_ _ N N _ Never

3. I have attended Florida Counties Foundation (FCF) educational programs in the past.

Yes $\quad$ No

4. The total number of FCF educational programs I attended in the last year is:

_ None __ One Two or three __ _ More than three

5. I find the FCF/CCC educational programs I attended to be beneficial?

_ Always __ Sometimes___ Rarely __ N __ Never

6. I prefer to attend:

_ Weekday Workshops Weekend Workshops Sunday/Monday Workshops

7. My preference for workshop length/time is:

Half Day (3 hours) __ _ Whole Day (6 hours) ___ Multiple Days
Evenings

8. I prefer workshops that cover:

Single subjects/issues (example: budgeting)

Multiple subjects/issues (example: budgeting, ethics, conflict resolution)

9. To cover the costs of the enhancement and expansion of the Foundation's educational program, I would be willing to increase the $\$ 75$ registration fee to: 
10. The most important factors in my attendance at workshops are: (please rank with 1 being least important and 5 being most important)

\begin{tabular}{lccccc} 
& $\begin{array}{c}\text { Least } \\
\text { Important }\end{array}$ & - & & Most \\
Topic & 1 & 2 & 3 & 4 & 5 \\
Fee & 1 & 2 & 3 & 4 & 5 \\
Date/Time & 1 & 2 & 3 & 4 & 5 \\
Location & 1 & 2 & 3 & 4 & 5 \\
Length (1/2, full day, etc.) & 1 & 2 & 3 & 4 & 5 \\
Certification Credit & 1 & 2 & 3 & 4 & 5 \\
\hline
\end{tabular}

11. The Commissioners Voluntary Certification Program should be continued.

Strongly Agree

Agree

Neutral

Disagree

Strongly Disagree

12. As an elected official, issues where I need training to help me do my job better (circle all that are important)
A. Devolution
N. Geographic Information Systems
B. Home Rule
O. Telecommunications
C. Planning \& Zoning
P. Negotiating Skills
D. Economic Development
Q. County Government Form \& Function
E. Financial Management
R. Media/Presentation Skills
F. Sunshine Law / Ethics
S. Personnel Policies / Labor Law
G. Environmental / Water / Landfill Issues
T. Constituent Relations
H. Conflict Resolution
U. Legislative Process
I. Leadership Training
V. Transportation Issues
J. Sexual Harassment
W. Public Safety Issues
K. Effective Communication
X. Health \& Human Services Issues
L. Sustainable Communities
Y. County Government Services
M. Other (please specify) 
13. As an elected official, the three issues identified in Question 12 where I need training most to help me do my job better are: (please identify by alphabetical character)

Most important

Second most important

Third most important

14. As an elected official, issues where our county staff need training most to help improve our county government are: (circle all that are important)

\begin{tabular}{llll}
\hline A. & Devolution & N. & Geographic Information Systems \\
B. & Home Rule & O. & Telecommunications \\
C. & Planning \& Zoning & P. & Negotiating Skills \\
D. & Economic Development & Q. & County Government Form \& Function \\
E. & Financial Management & R. & Media/Presentation Skills \\
F. & Sunshine Law / Ethics & S. & Personnel Policies / Labor Law \\
G. & Environmental / Water / Landfill Issues & T. & Constituent Relations \\
H. & Conflict Resolution & U. & Legislative Process \\
I. $\quad$ Leadership Training & V. & Transportation Issues \\
J. Sexual Harassment & W. & Public Safety Issues \\
K. Effective Communication & X. & Health \& Human Services Issues \\
L. & Sustainable Communities & Y. & County Government Services \\
M. & Other (please specify) & & \\
\hline
\end{tabular}

15. As an elected official, the three issues identified in Question 14 where our county staff need training most to help improve our county government are: (please identify by alphabetical character)

Most important

Second most important

Third most important

16. I have been in my current position:

Less than 2 years

3-8 years

8-12 years

More than 12 years

\section{(OPTIONAL)}

NAME

COUNTY 


\title{
1998-2000 County Commissioner Educational Survey
}

\author{
Rodney L. Clouser
}

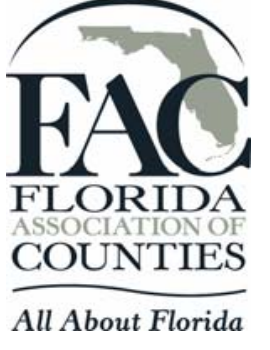




\section{Attend FAC Annual Conference (Percent)}

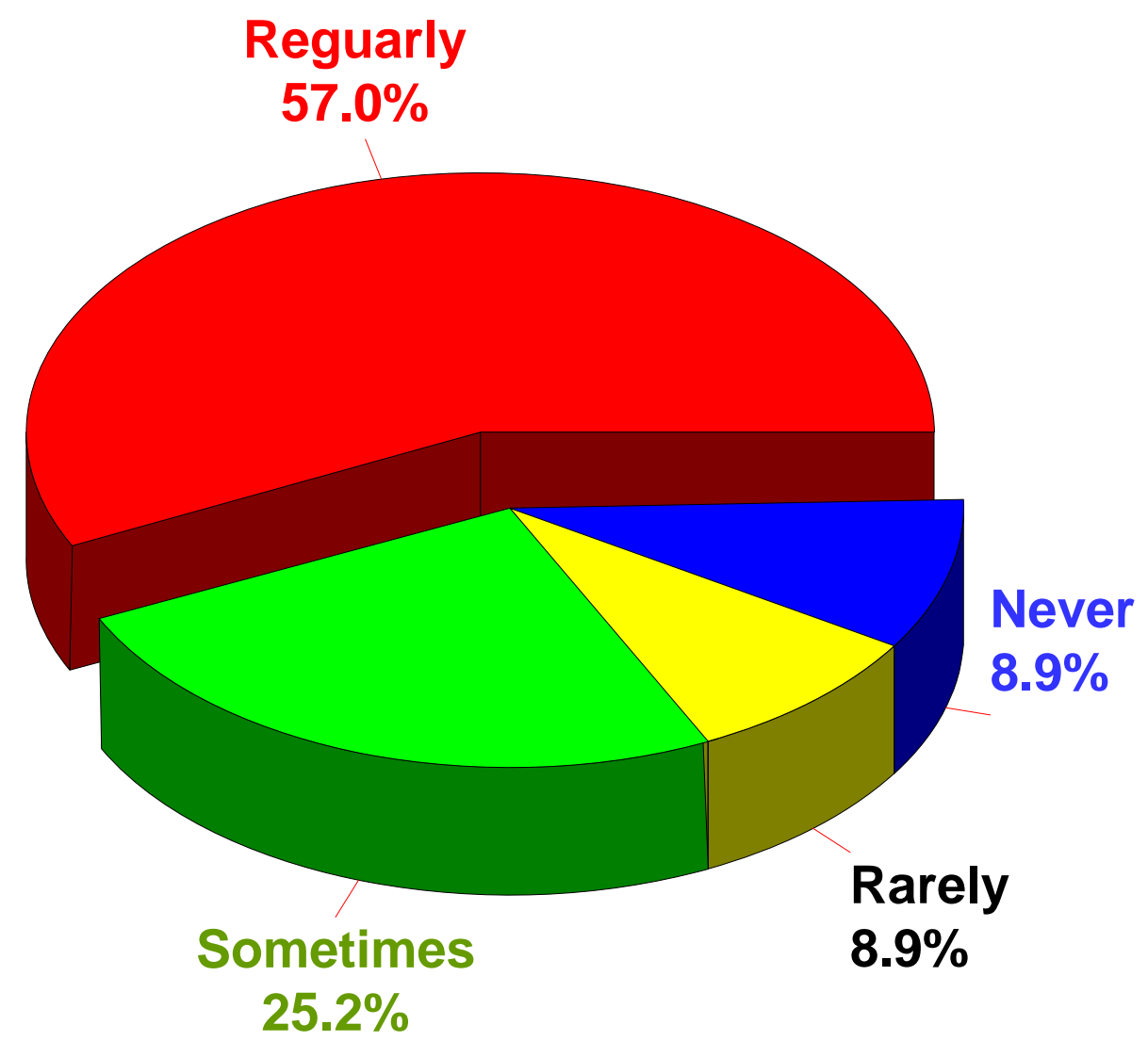

Q1 


\section{Attend FAC Legislative Conference}

\section{(Percent)}

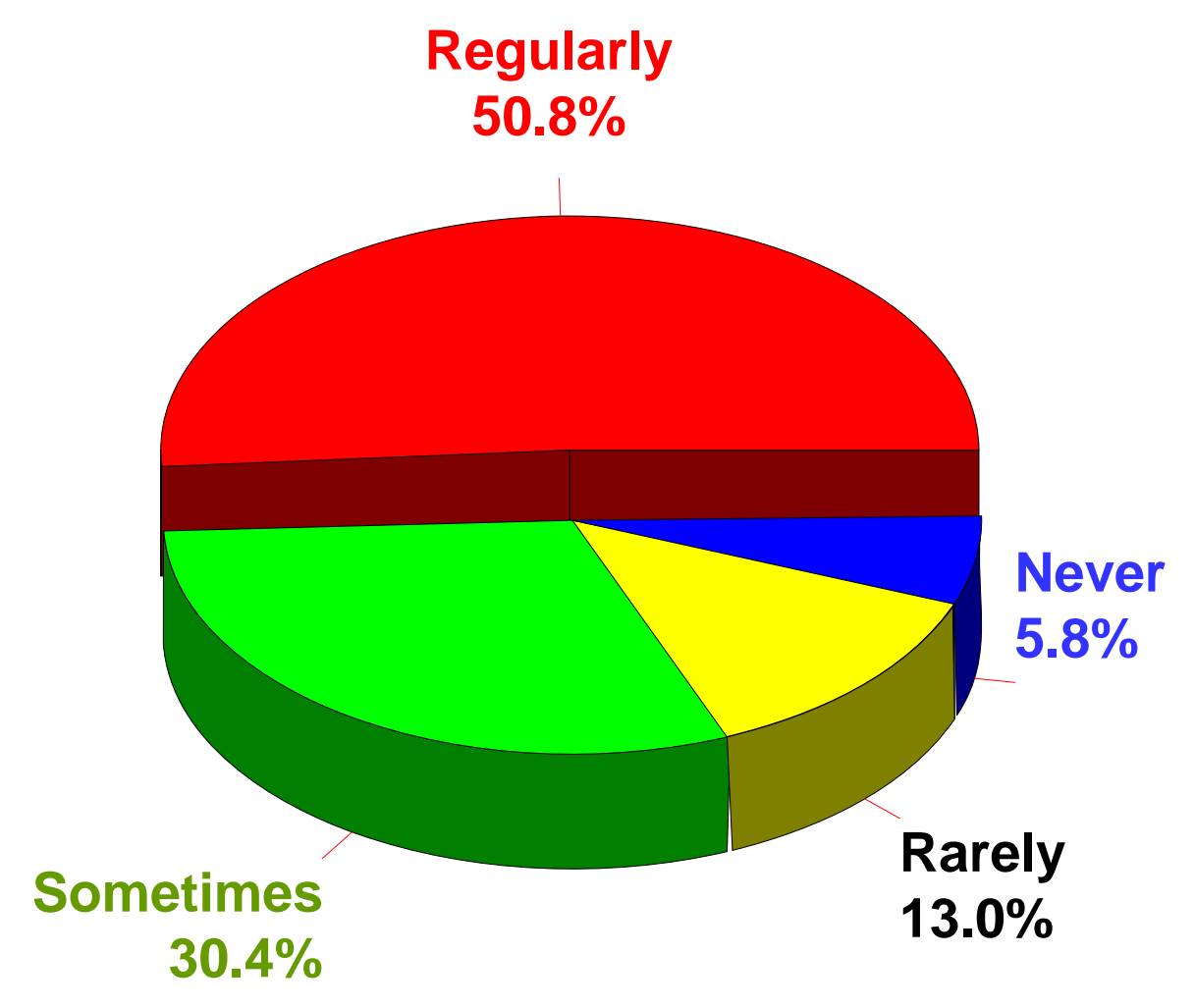

Q2 


\section{Attend FAC Educational Programs \\ (Percent)}

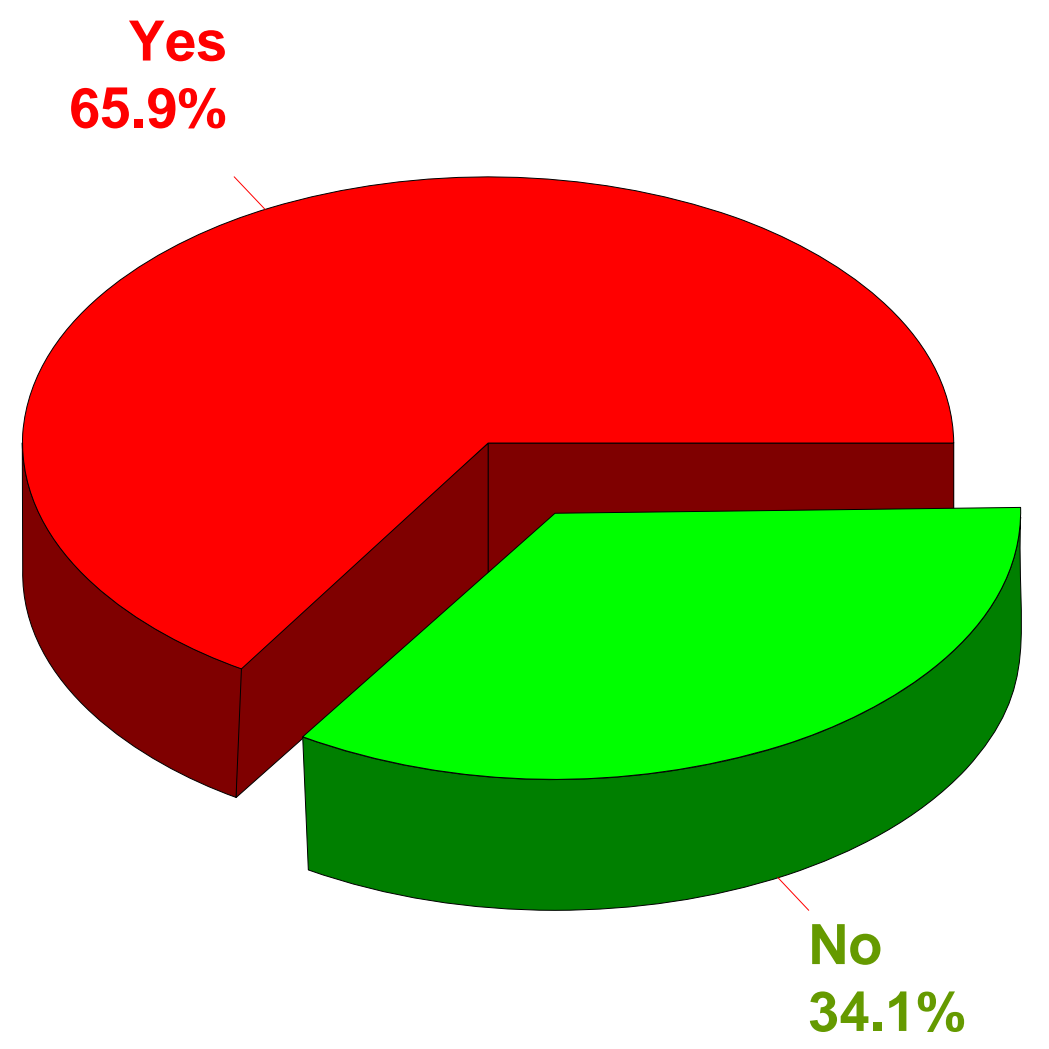

Q3 


\section{Number of Educational Programs Attended (Percent)}

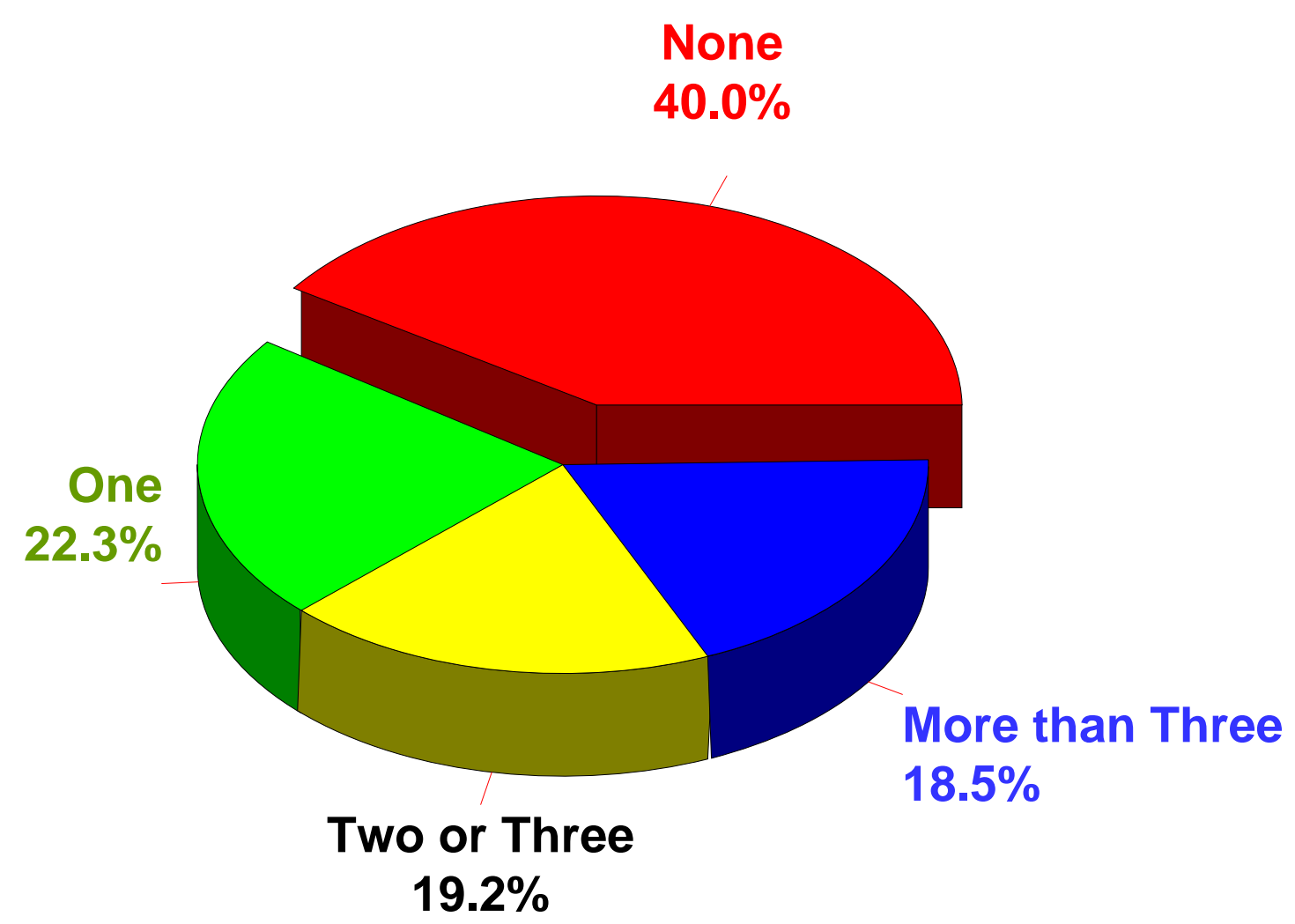




\section{Find FAC Programs Beneficial (Percent)}

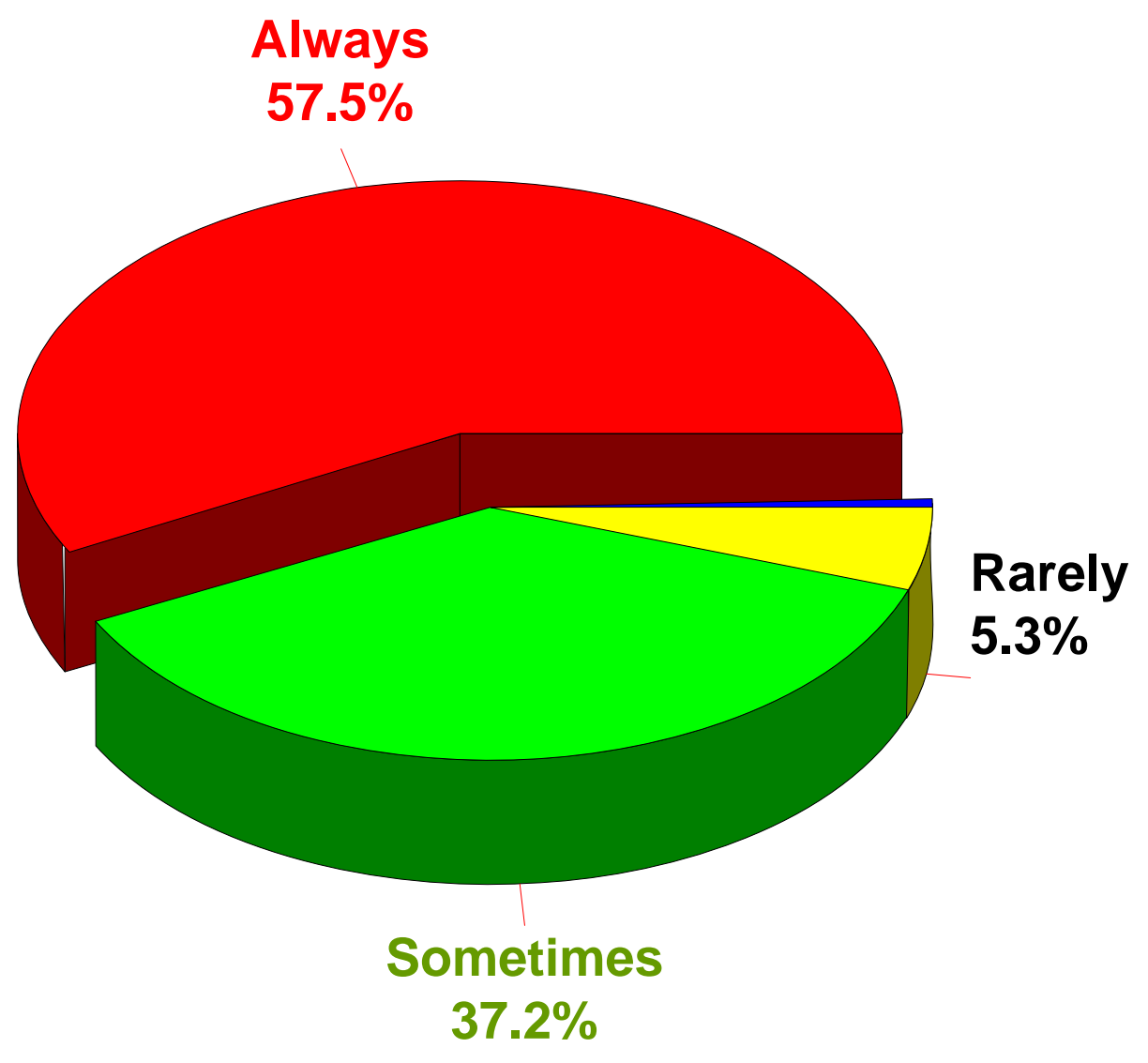

Q5 


\section{Workshop Preference - Day (Percent)}

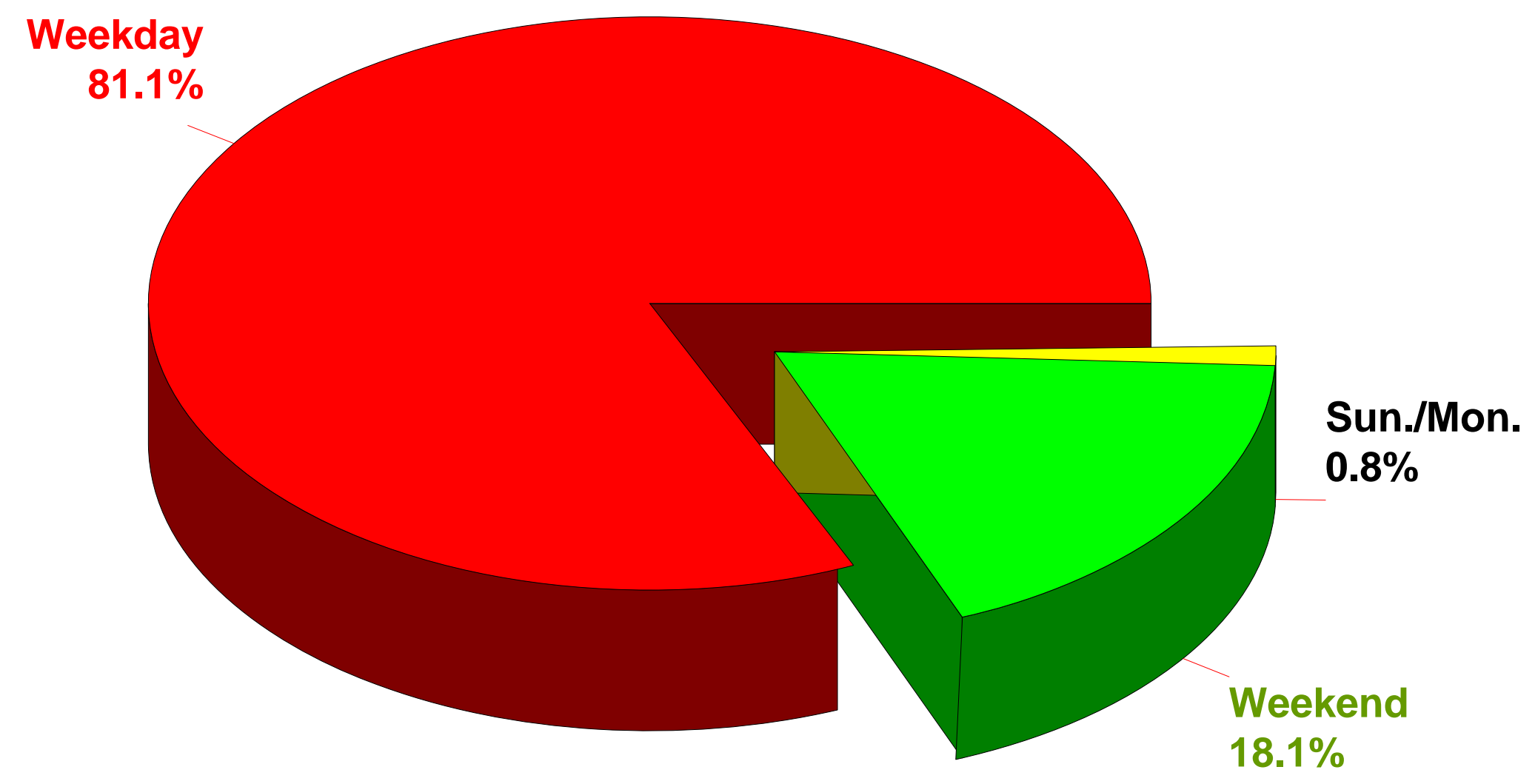




\section{Workshop Preference - Time Whole Day (Percent)}

$63.0 \%$

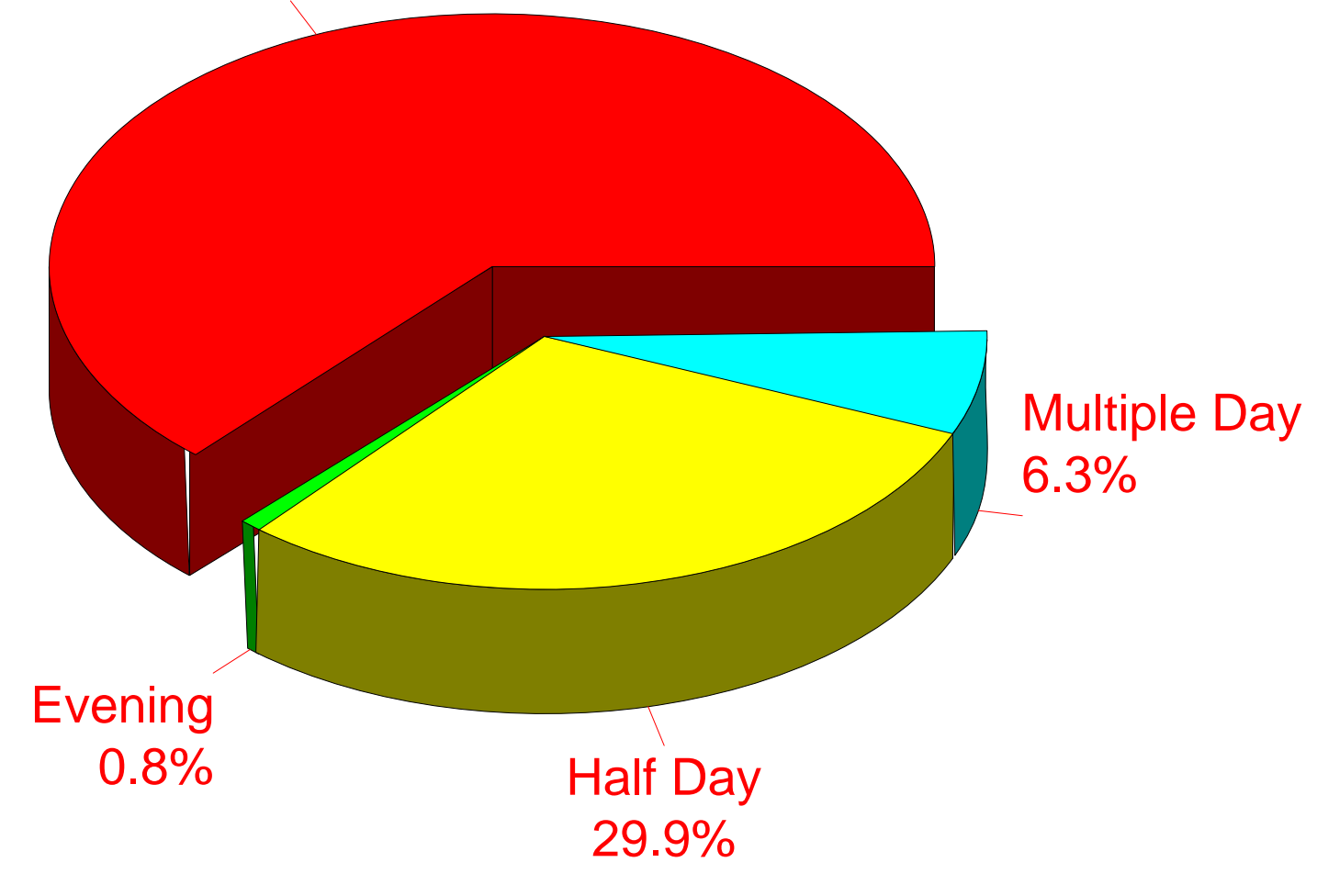

Q7 


\section{Workshop Subjects (Percent)}

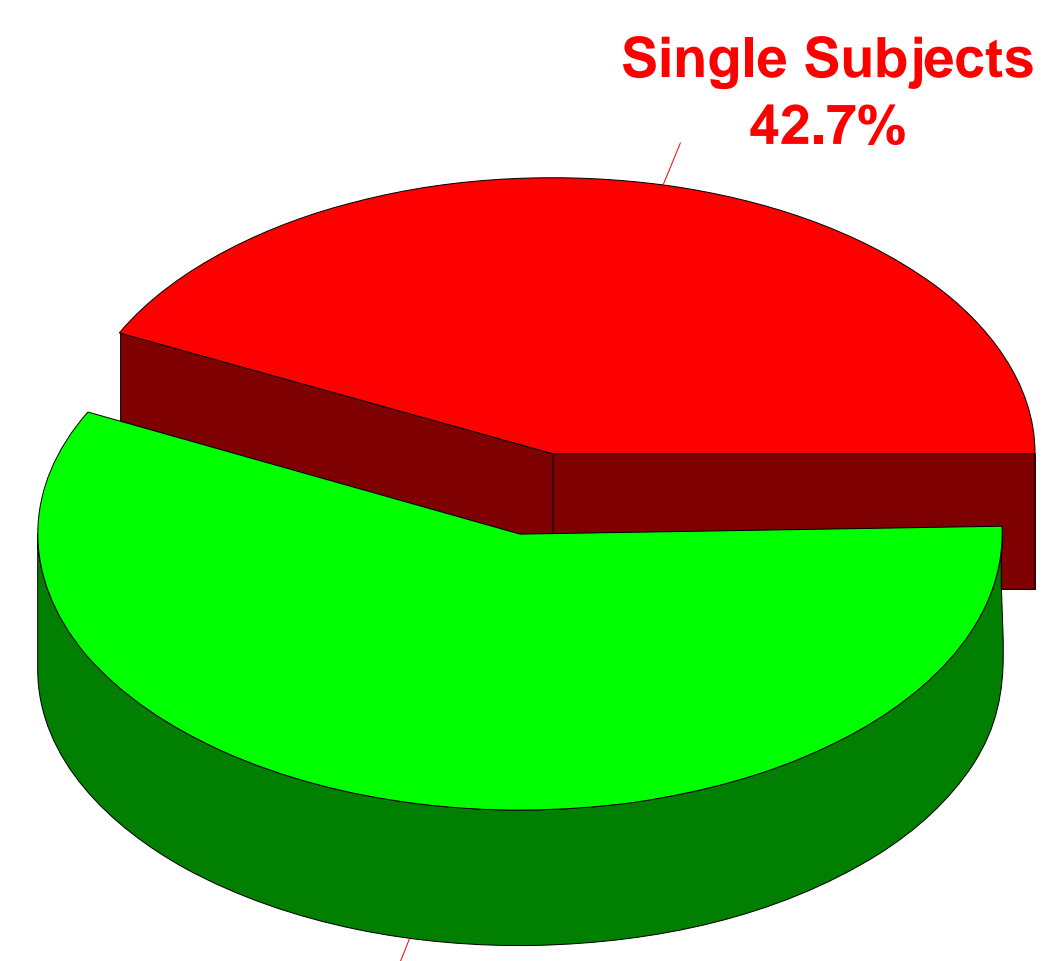

Multiple Subjects

$57.3 \%$ 


\section{Workshop Fees \\ (Percent)}

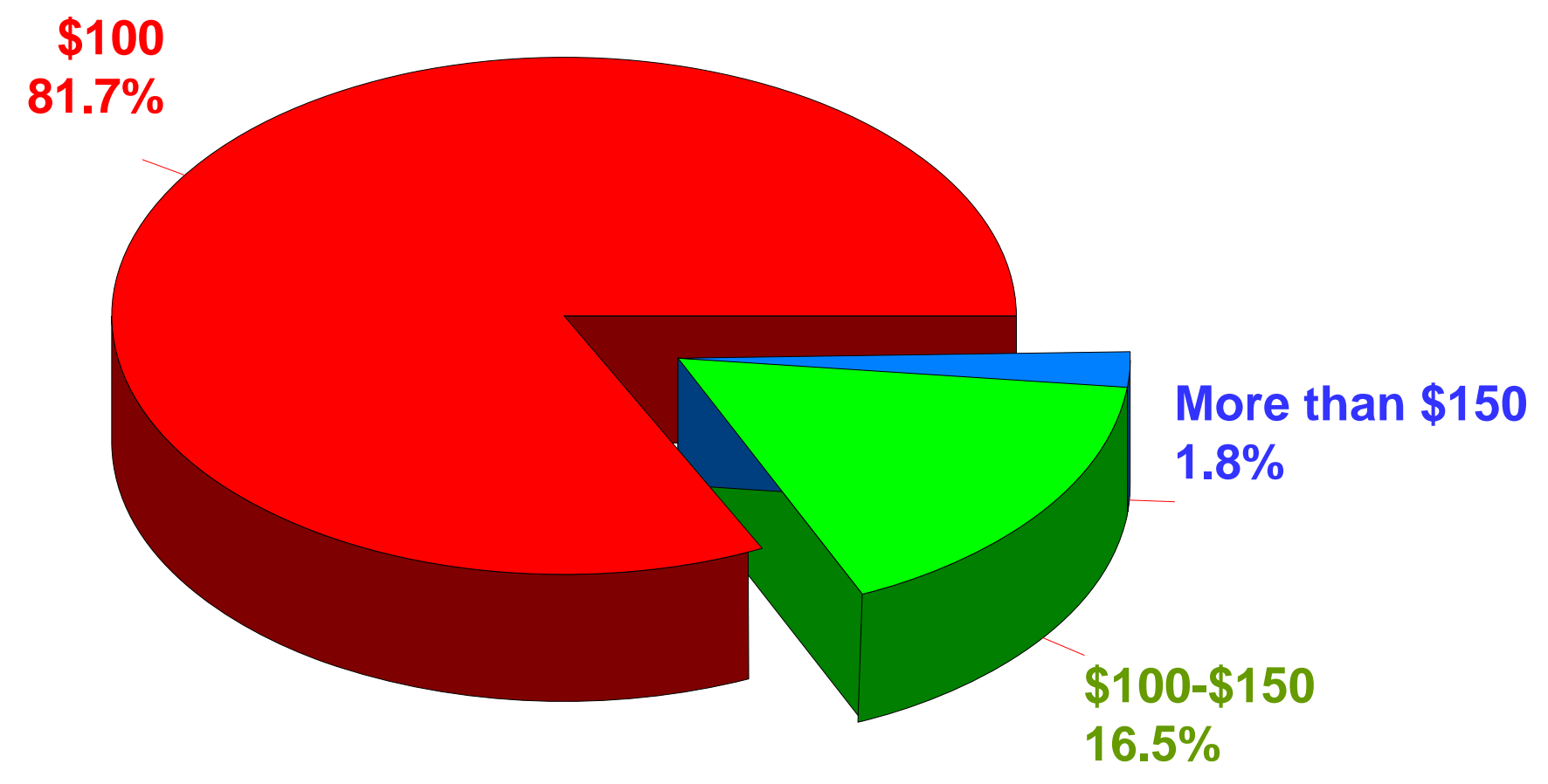

Q9 


\section{Factors Influencing Attendance}

\section{(Percent)}

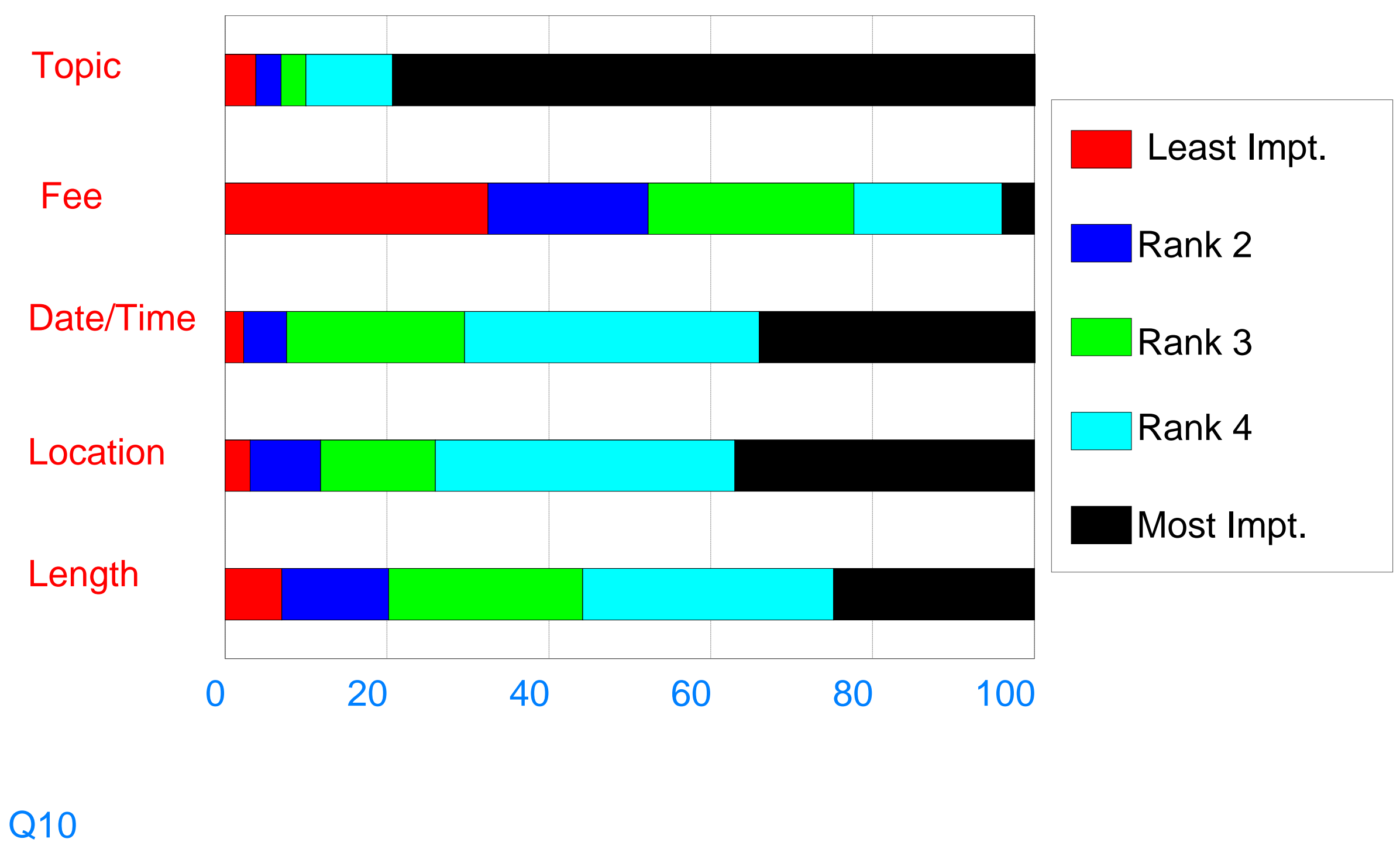




\section{Continue Voluntary Certification (Percent)}

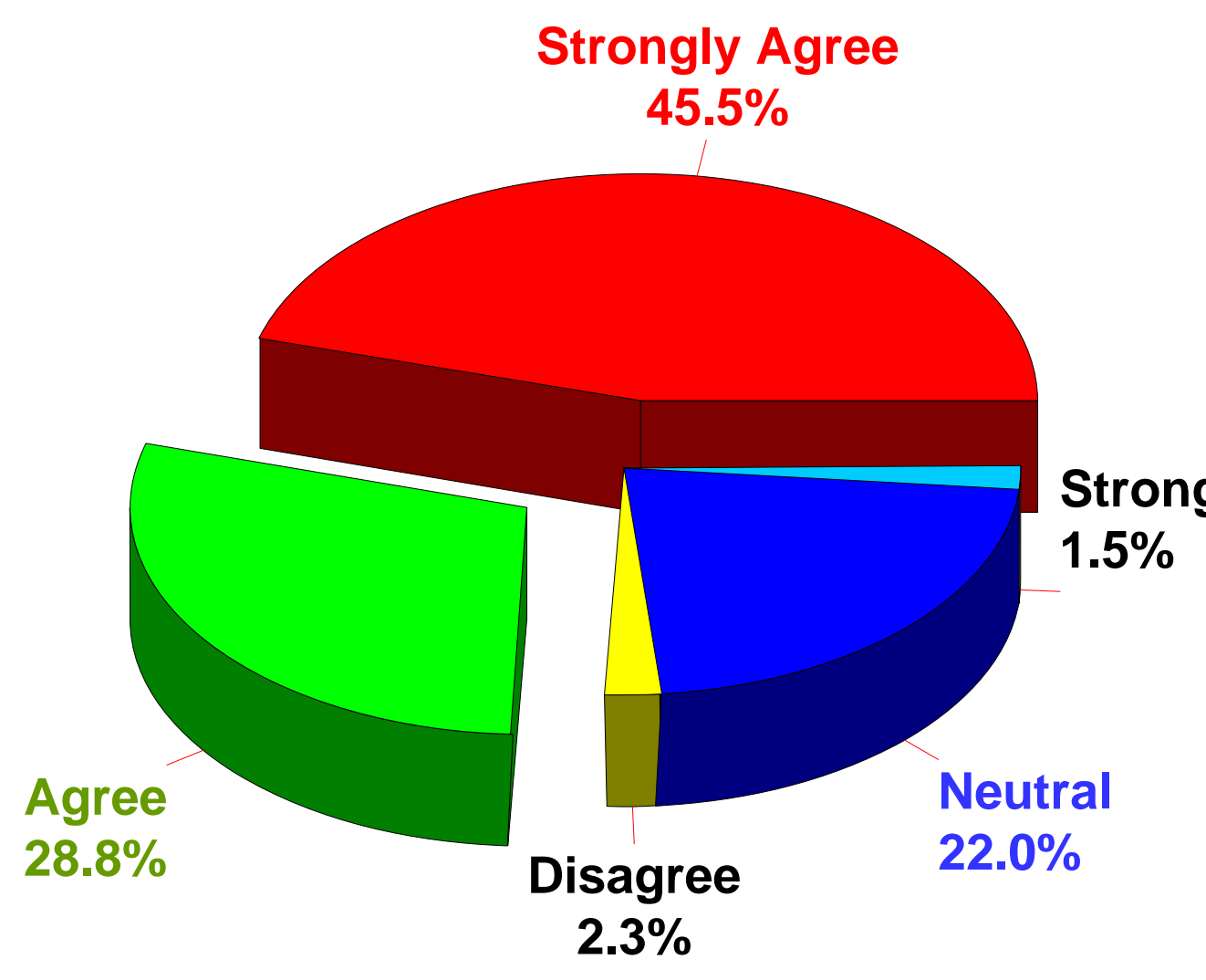

Q11 


\section{Most Important Issues - Commissioners}

(Number of Responses)

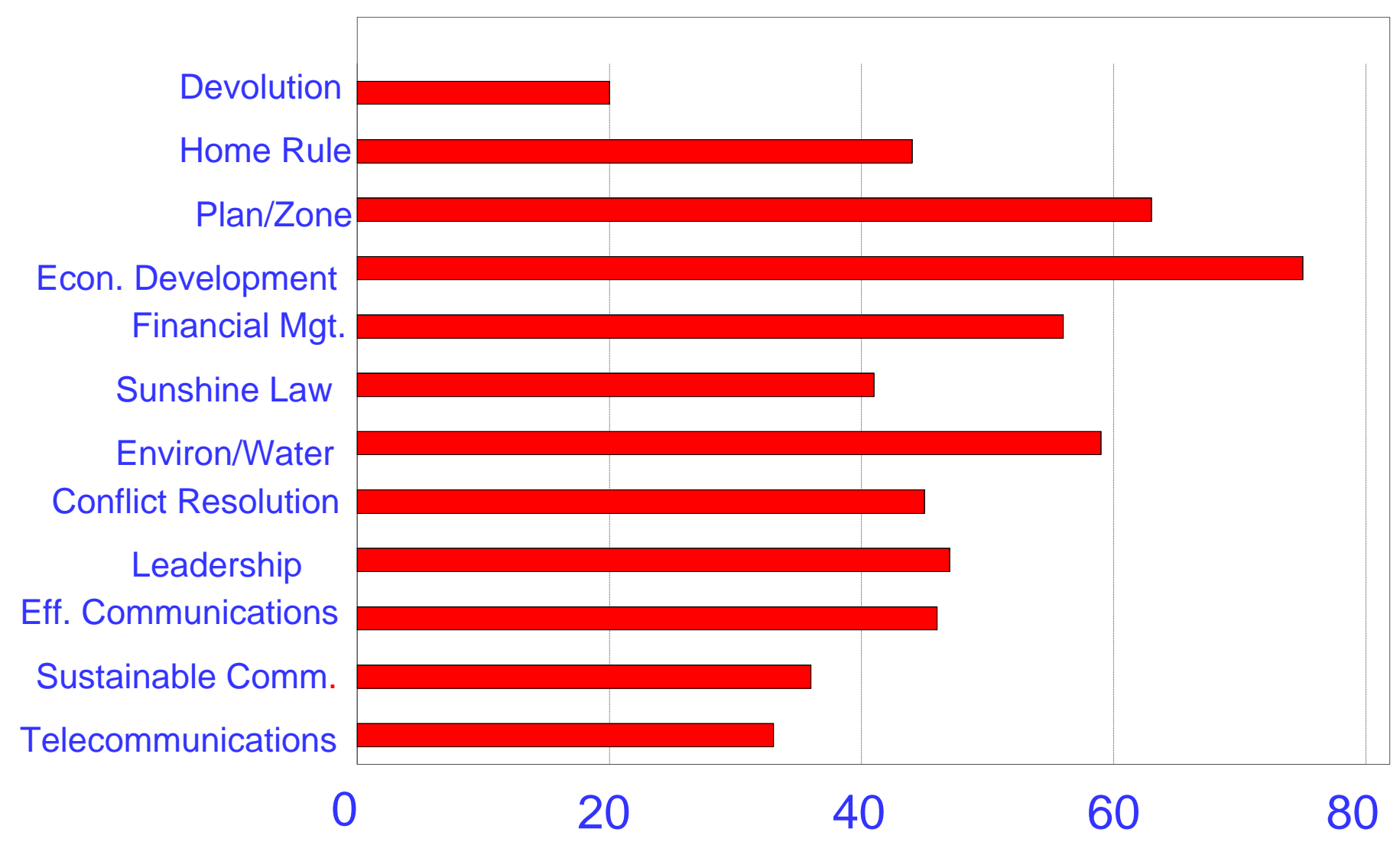

Q12A 


\section{Most Important Issues - Commissioners (Number of Responses)}

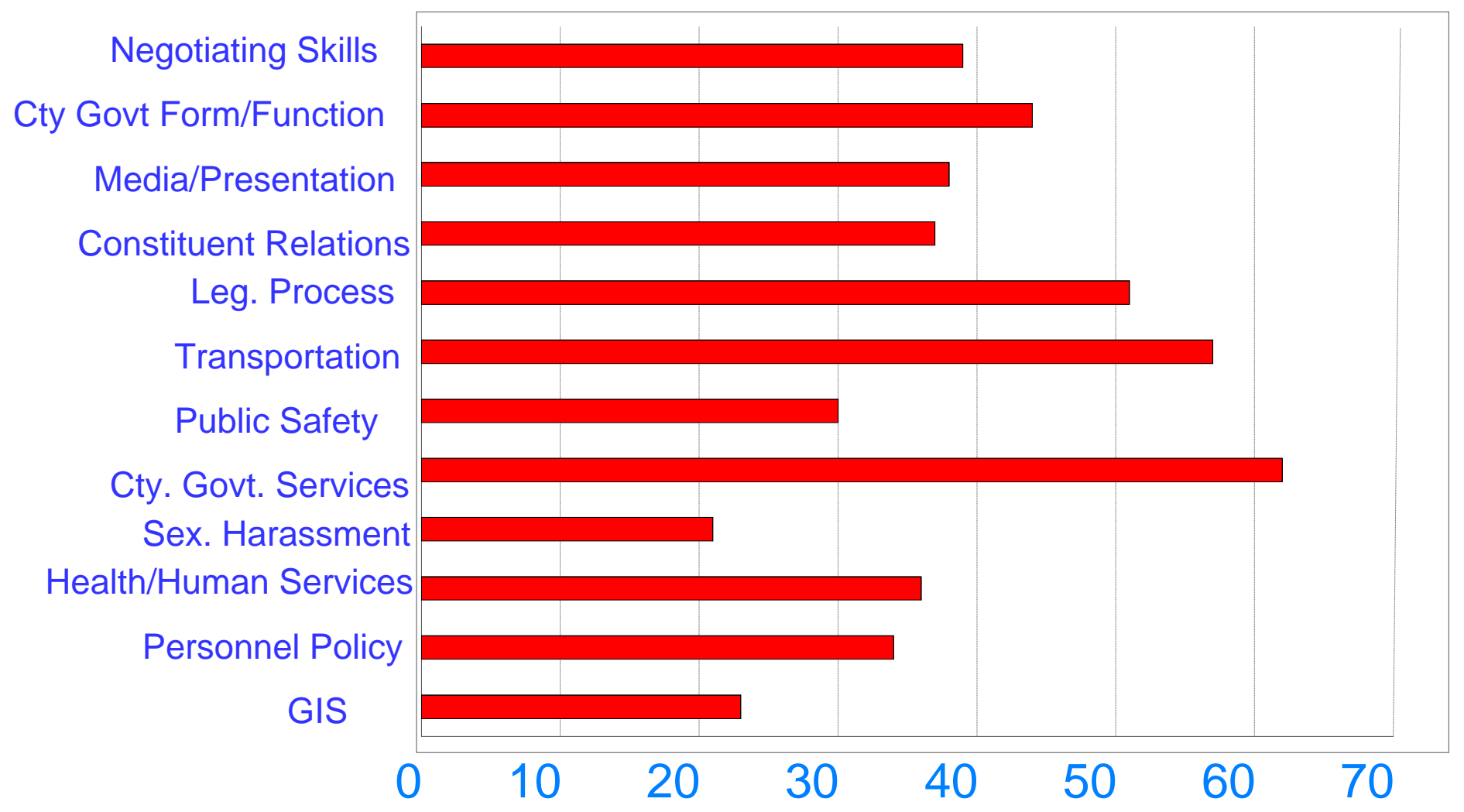

Q12B 


\section{Most Important Issues - Commissioners}

\section{(Number of Responses)}

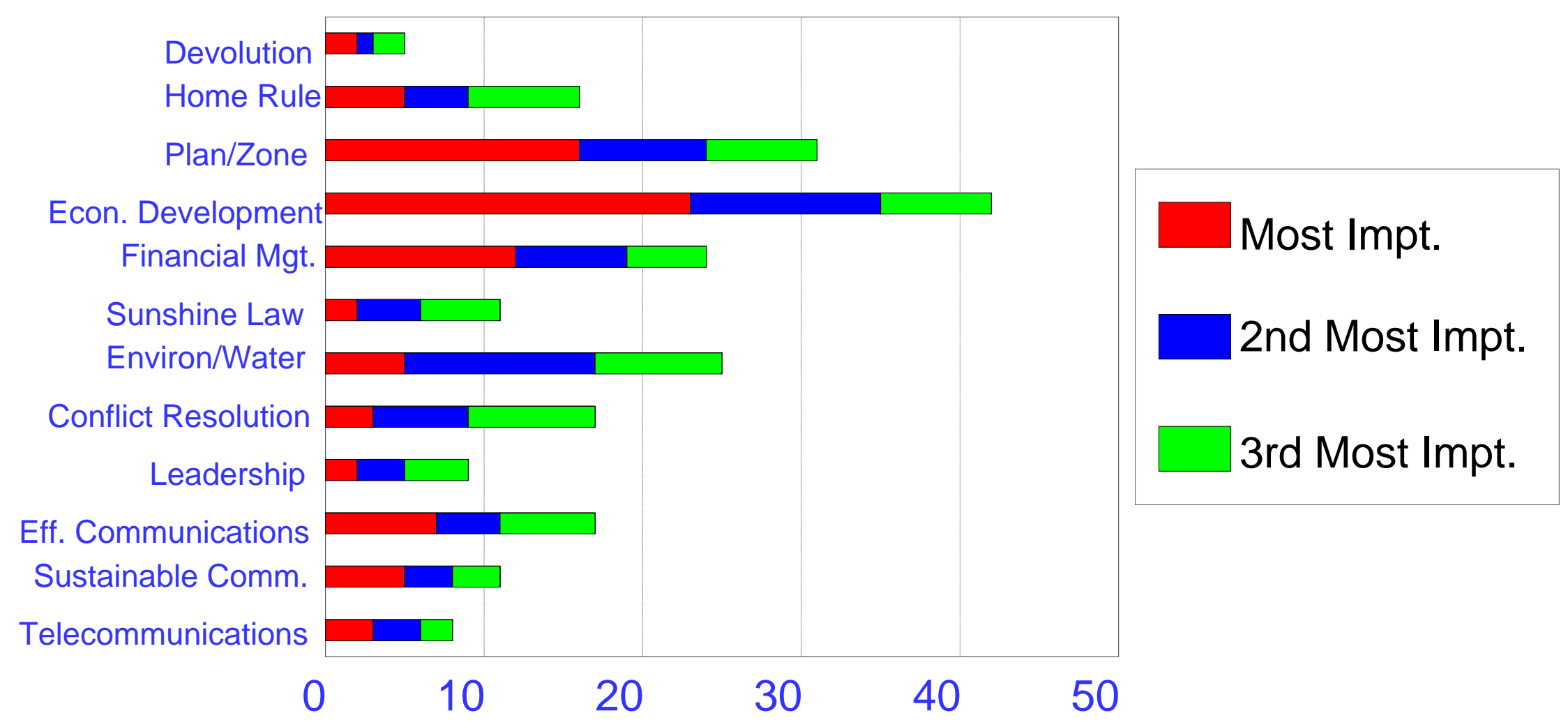




\section{Most Important Issues - Commissioners (Number of Responses)}

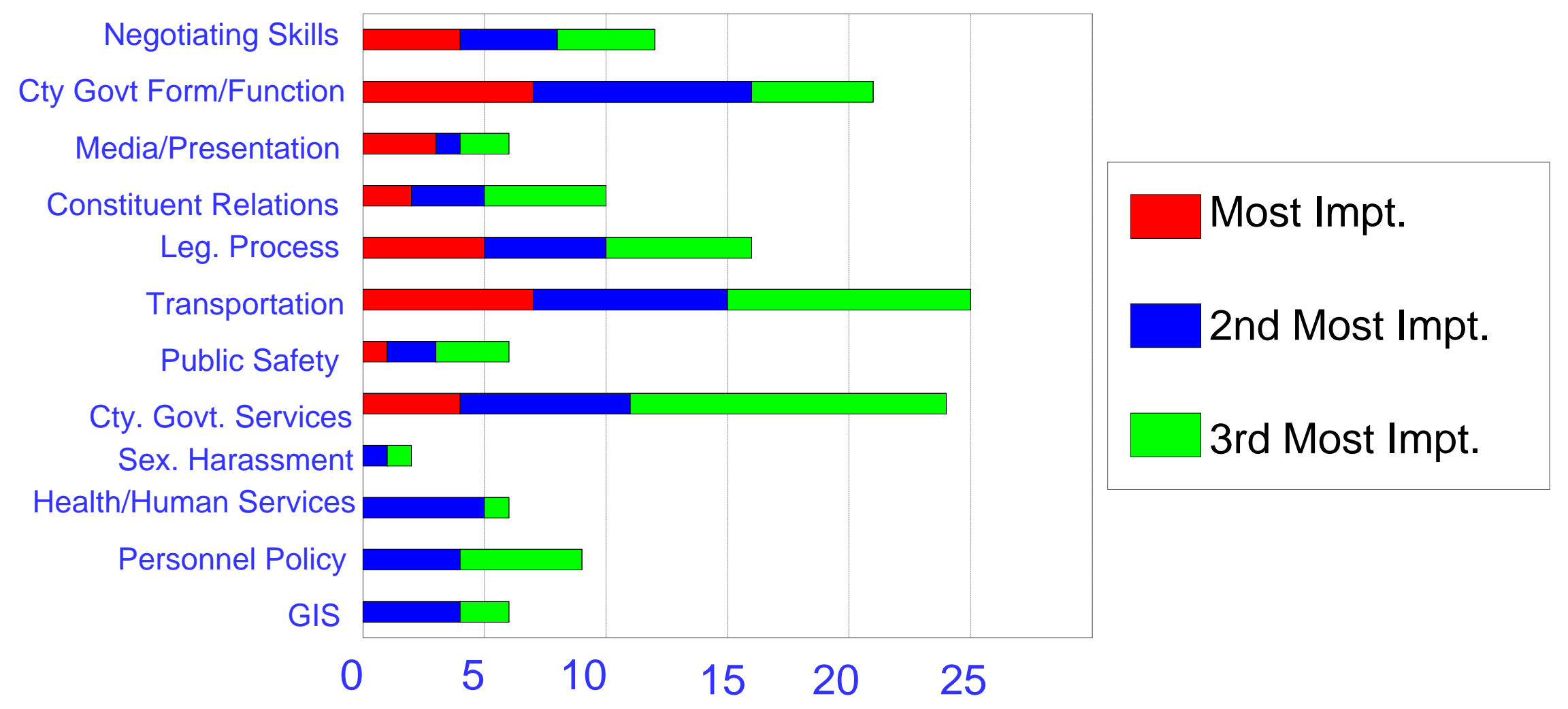




\section{Most Important Issues - Staff}

\section{(Number of Responses)}

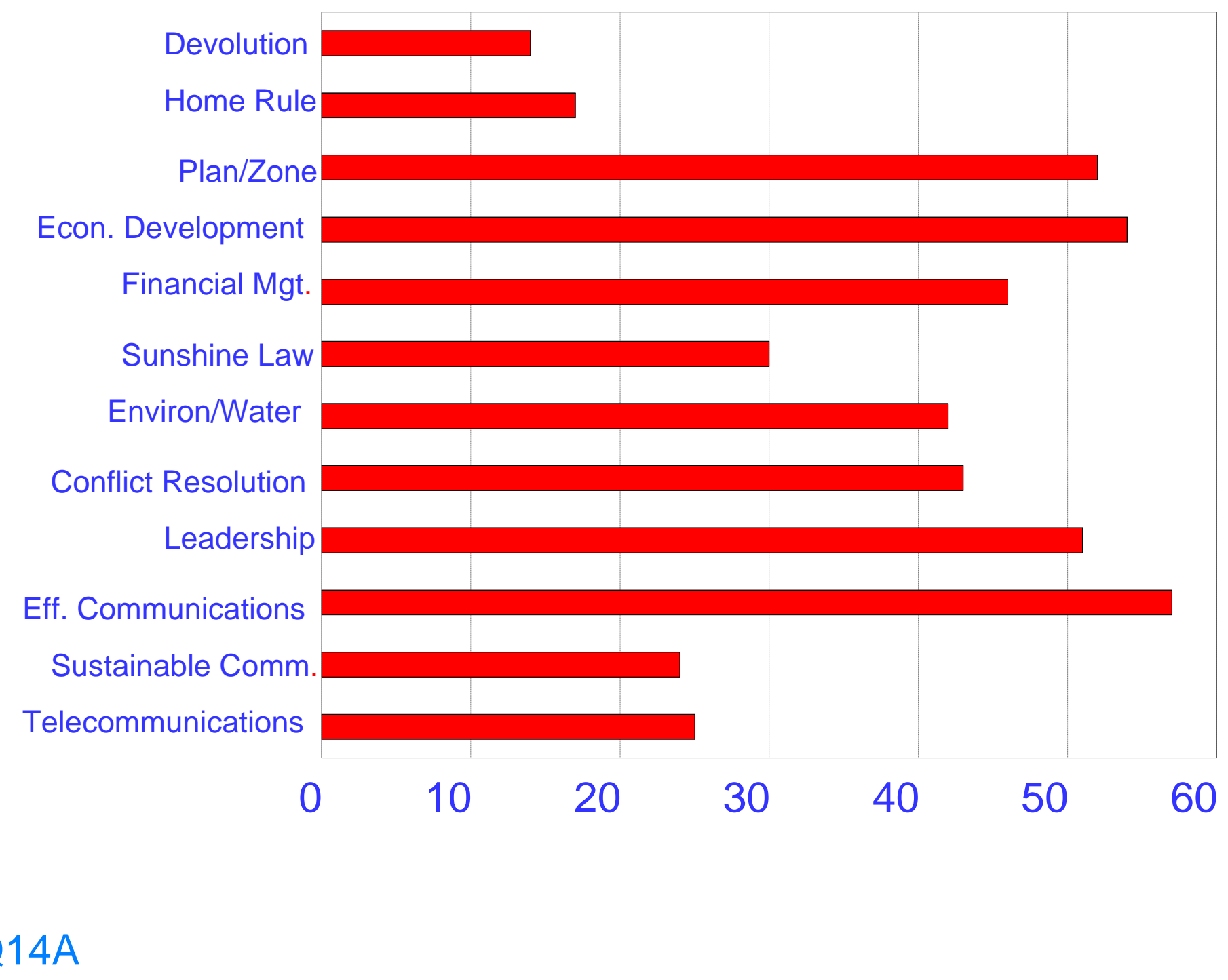




\section{Most Important Issues - Staff}

\section{(Number of Responses)}

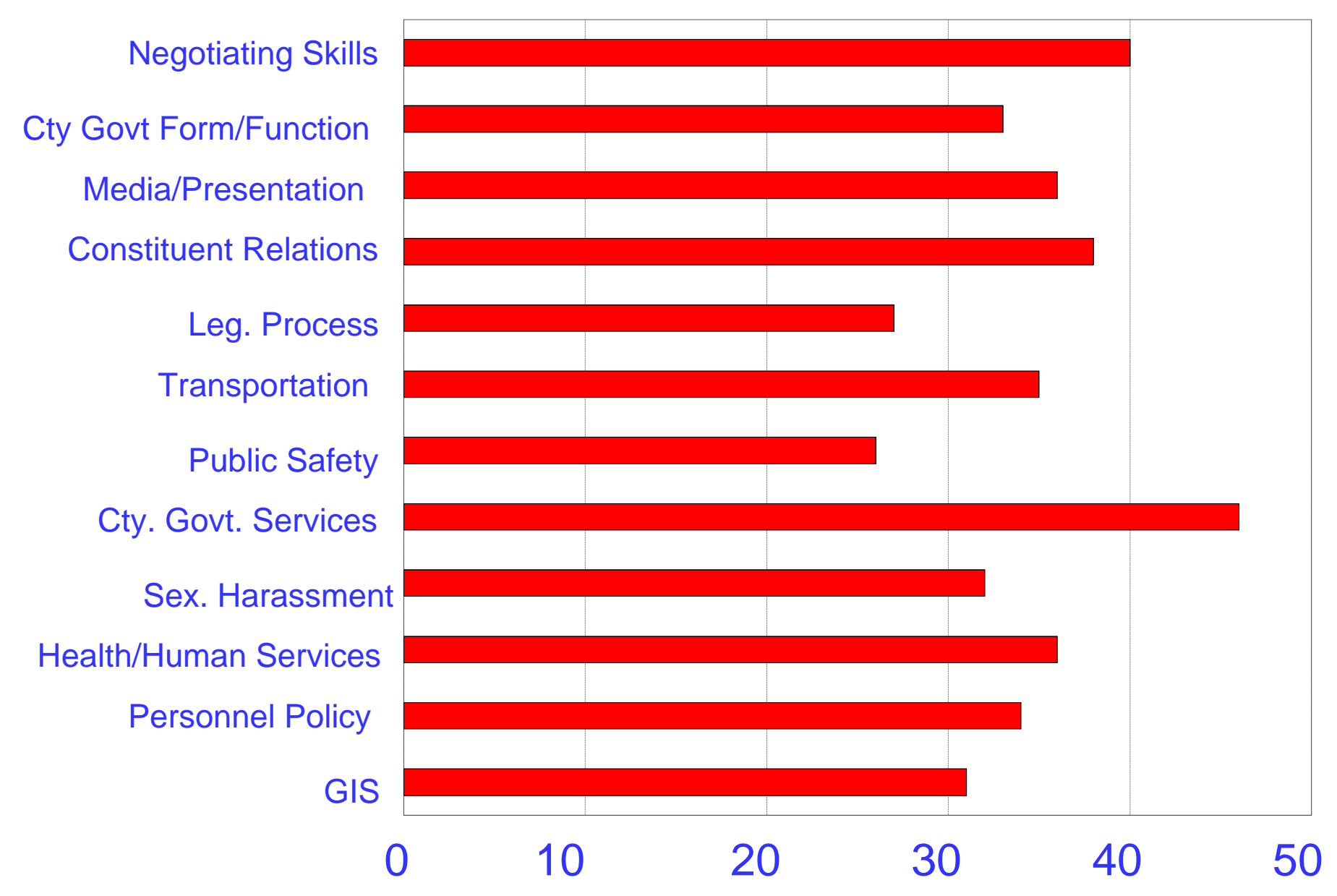




\section{Most Important Issues - Staff (Number of Responses)}

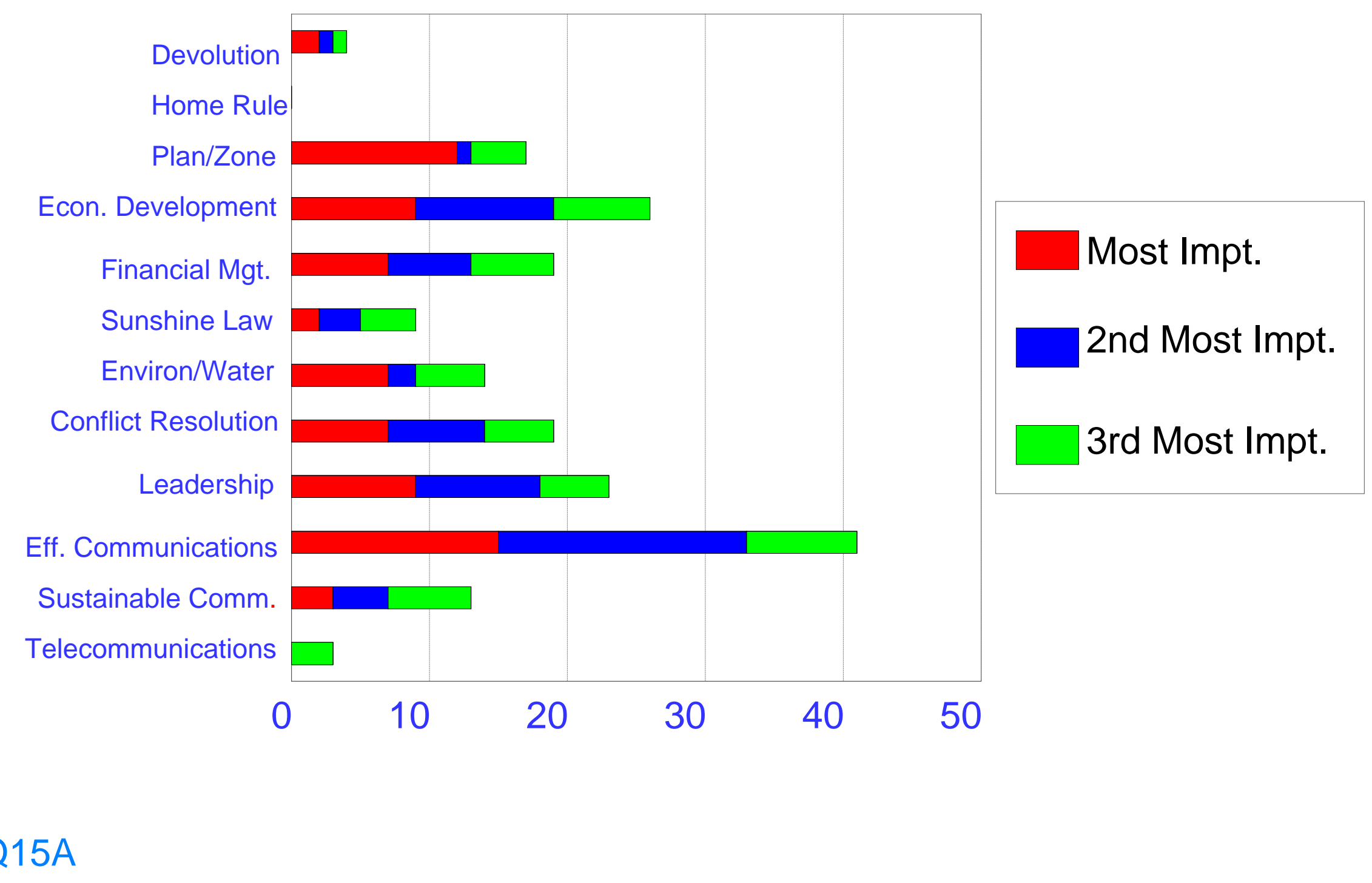




\section{Most Important Issues - Staff (Number of Responses)}

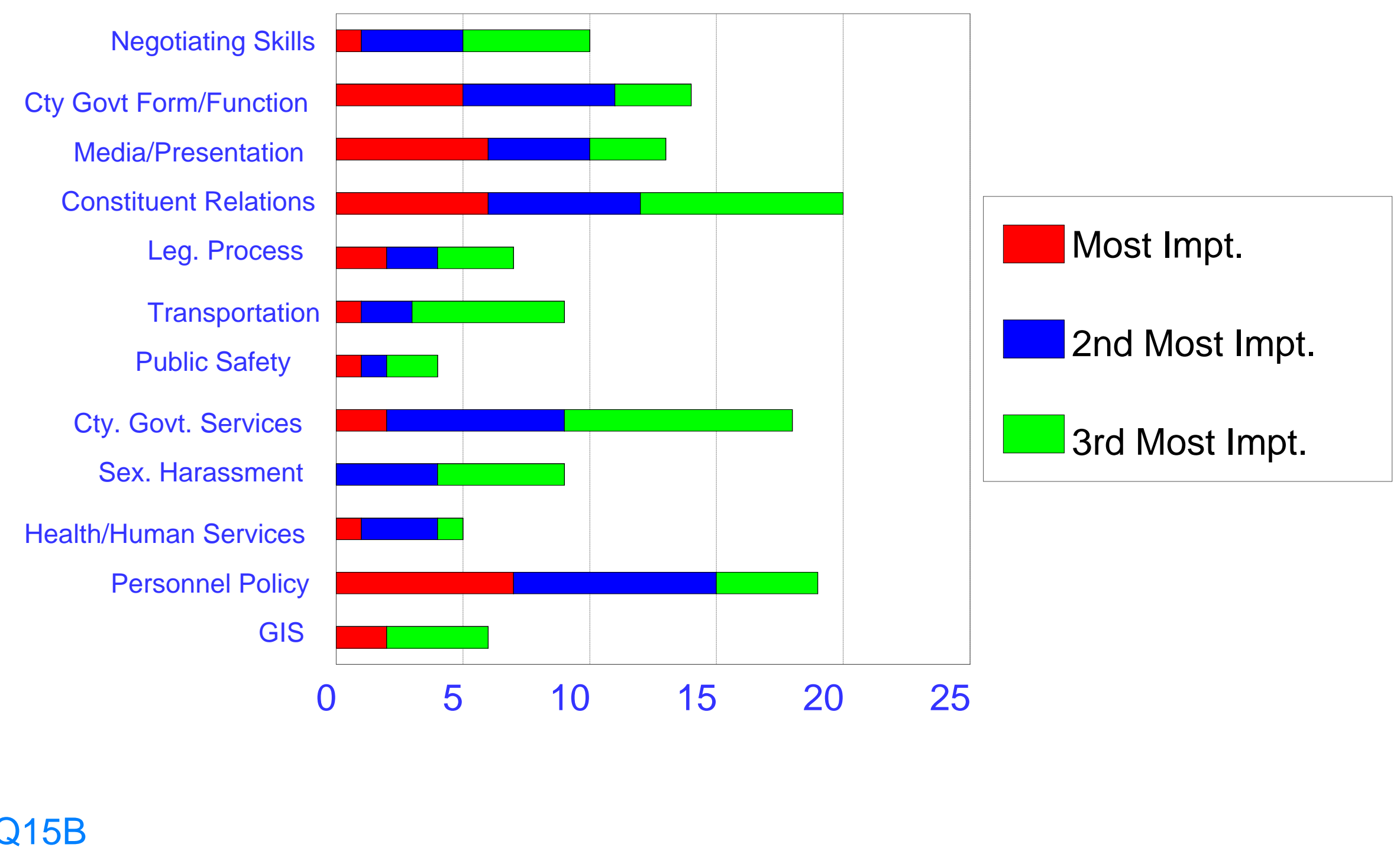




\section{Years in Current Position (Percent)}

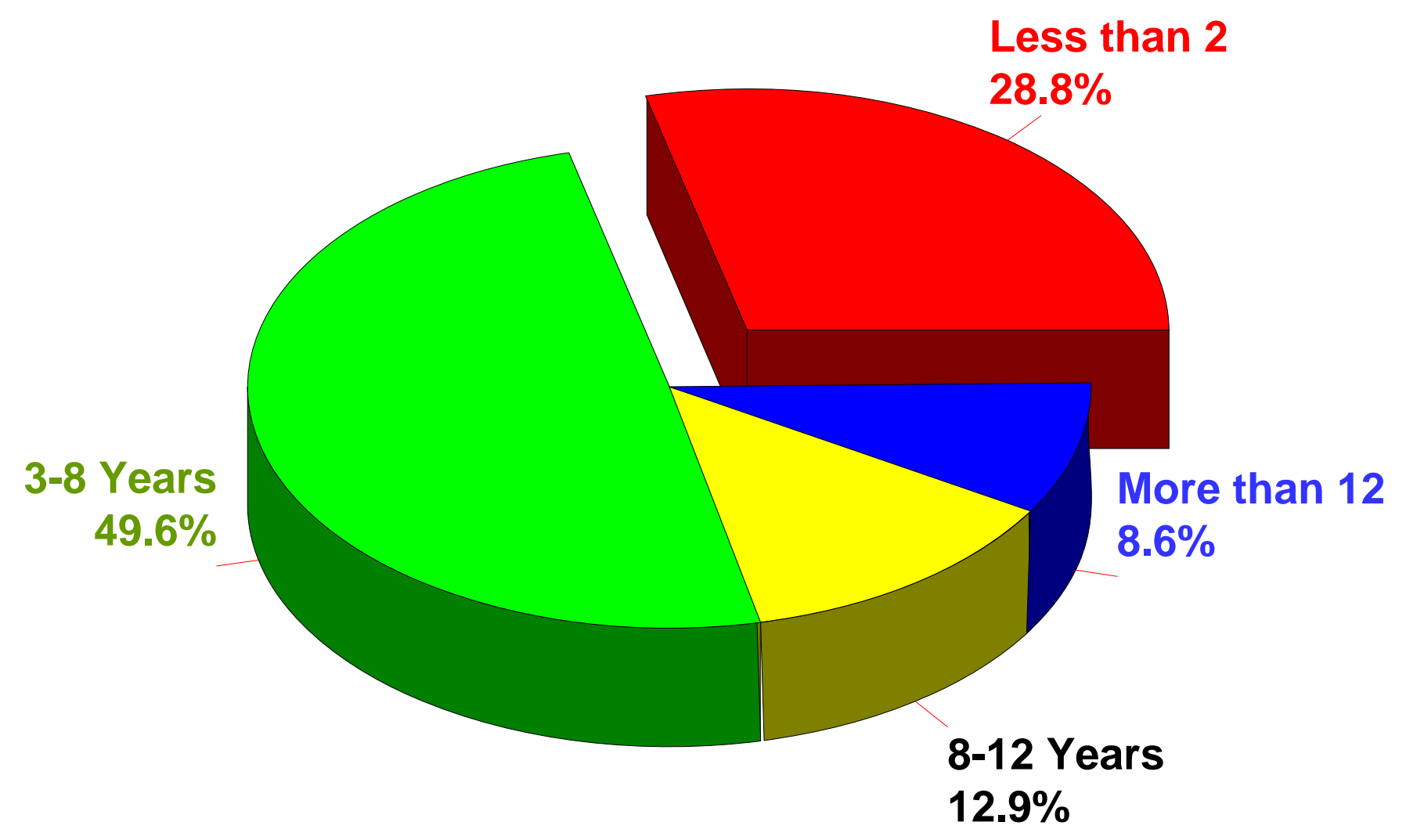

Q16 